\title{
Ways of soil development on stony substrate from hard coal mining spoil
}

\author{
Wolfgang Burghardt*1, Monika Niggemeyer ${ }^{1}$, Martin Braunersreuther ${ }^{1}$ \\ ${ }^{1}$ University Duisburg-Essen, Faculty of Biology, Soil Technology, Universitaetsstr. 5, 45141 Essen, Germany \\ * Prof. Dr. W. Burghardt, wolfgang.burghardt@uni-due.de
}

Received: 31.08.2020

Accepted: 15.01.2021

Associated editor: $Ł$. Uzarowicz

\section{Keywords}

Hard coal mining spoil

Stones

Soil formation

Bulk density

Carbon stock

Sulfur content

\begin{abstract}
The effect of stones on soil development is presented with the example from a hard coal mining spoil. The investigation concerns the stone and fine earth content, total bulk density, bulk density of the stone and fine earth fractions, pore volume, total carbon, organic carbon and sulfur content, as well as pH. Samples were taken from two different mine spoil depositions, the Monopol and Achenbach spoils, of the vegetation trial at Waltrop in the Ruhr area, Germany. Sampling occurred at the start of the trial and at two times, 8 and 14 years later, respectively. The samples were taken in big rings which were pushed into the mine spoil soil. The depth intervals of samples were tight with $0-2,2-5,5-10$ and $10-20 \mathrm{~cm}$ below surface. Total organic carbon (TOC) and sulfur content and the $\mathrm{pH}$ were measured using standard methods. TOC was determined by destruction with $\mathrm{H}_{2} \mathrm{O}_{2}$. This proved to be a reasonable method which is relatively easy to perform. Soil formation occurred very fast, within eight years, in substrate with stone content by weight of $60-80 \%$. However, the way of soil formation differed between the Monopol and Achenbach mining spoils. The results indicate that in Monopol spoil, accumulation of TOC occurred by the intrusion of fine earth into pores between stones. However, in Achenbach spoil, fine earth was formed by the weathering of stones. The TOC content of fine earth achieved 8 to $16 \mathrm{mg} \mathrm{g}^{-1}$. The TOC stock within $20 \mathrm{~cm}$ depth and $1 \mathrm{~m}^{2}$ of the Monopol and Achenbach spoils was 1.0 and $0.6 \mathrm{~kg}$, respectively. This is a very low value compared to the up to $12 \mathrm{~kg}$ in $1 \mathrm{~m}$ depth of the farmland soils of the region. The mine spoils contain between 2 and $18 \mathrm{mg} \mathrm{g}^{-1}$ sulfur. Formation of sulfuric acid by the oxidation of sulfides in the spoil decreased the $\mathrm{pH}$ from 7.6 at the start of the trial to around pH 4.5 after 8 and 14 years in the Achenbach spoil. In the Monopol spoil, the $\mathrm{pH}$ increased with depth from $\mathrm{pH} 5.5$ to 7.2. A negative relationship exists between $\mathrm{pH}$ and pore volume for the Monopol spoil. Due to the TOC accumulation of more than $6 \mathrm{mg} \mathrm{g}^{-1}$, the soils can be classified as Regosols from hard coal mining spoil substrate in the German classification system. Within US Soil Taxonomy, the soils would belong to the Entisols. In the WRB soil classification, the soils can be positioned to the Leptosols, with the qualifiers Technic, Skeletic and as an additional qualifier Sulfuric and Intrusic or alternative to the Technosols with the qualifiers Spolic, Skeletic, Sulfuric and Intrusic. The occurrence of stony spoil deposits from deep hard coal mining in the loess belt from Eastern France to Eastern Ukraine changed large areas of originally rich fertile soils to poor soils, but promoted the bio-diversity.
\end{abstract}

\section{Introduction}

About the importance and effects of stones in soils exists only few research contributions (Flint and Childs, 1984; Nichols et al., 1984; Hantschel et al., 1992; Schulin et al., 1995; Niggemeyer and Burghardt, 1996; Burghardt, 1997). The effect of stone content on the properties of soils in urban, industrial and mining environments, the SUITMA soils (Soils of urban, industrial, traffic, mining and military areas, Burghardt et al., 2015), was highlighted by Burghardt, 1994. One extreme of stone content in soils, are soils from hard coal deep mining spoils. They are the focus of this publication.
Soils from stone cover are a typical feature of hard coal deep mining areas. Recently hard coal mining areas became of particular interest because of the finding that the release of $\mathrm{CO}_{2}$ in the atmosphere by coal burning is a main cause of climate change. The consequence will be that coal age will end in the near future, at least in Europe (Alves Dias et al., 2018). Coal for energy generation will be no longer extracted and burnt. What is left besides the $\mathrm{CO}_{2}$ contamination of atmosphere is a huge amount of stony coal mining spoil which now forms new, human-made mountainous landscapes in mining areas. In the hard coal mining areas of the Ruhr in Germany, approximately $25 \mathrm{~km}^{2}$ are covered by coal mining spoil (Schneider, 1989). 
Not vegetated, hard coal mining spoil heaps form cool, unfriendly black landscapes, and are sources of dust and of extreme temperature variations. Thus the living quality for humans in former mining areas is affected. To overcome this, the mining spoil is subject to greening, mostly by tree plantation (Pietrzykowski and Krzaklewski, 2018). In respect of greening of the abandoned mining regions, mine soils become of importance (Down, 1975; Jochimsen, 1987, 1989, 1996, 2001; Maiti and Saxena, 1998; Maiti and Ghose, 2005; Sheoran et al., 2010; Kompała-Bąba et al., 2019). Of particular interest is the high contribution of stony soils from hard coal mining spoil to bio-diversity (Zimmermann and Burghardt, 1987; Weiss et al., 2005; Woch et al., 2013; KompałaBąba et al., 2019). The question is, what will be the conditions for soil development, and how will the soil formation look like?

The texture of hard coal mining spoil can be diverse which will determine essential the properties and formation of soils from individual mining spoils. The texture differences are due to the processes of sedimentation during the geological era of Carboniferous and the ways of coal mining nowadays. The process of hard coal formation started in the geological era Carboniferous in flat coastal areas. The decrease of land sinking during the phases of the Geosyncline in the Carboniferous era resulted in a reduction of slope between land and sea. Thus the eroded sediments transported into the coastal waters were first sand, followed by silt and finally clay, on which swamps with wooden peat were formed. The recurrence of subsidence covered the peat with mineral, mostly sandy layers. The peat material developed over more than 300 million years into hard coal. That means for the tailings of hard coal mining, they can be from schistose sandstone, silt stone and clay stone. They weather to sand, silt and clay (Kelly and Kelly, 1987). One can observe this at surface outcrops of layers of Carboniferous era. For example, Stagnic-Vertic Cambisols with mighty layers of high clay content and Stagnic properties or Podzols on weathered sandstone occur.

From recent mining operations occur tailings from mine shafts and from tunneling for the access to the coal layers, of mineral layers beside the coal bed and washing tailings from the separation of coal from minerals by washing. Most of the mine spoil is from washing tailings. Some of the earlier washing tailings can still have higher contents of up to $40 \%$ fine distributed coal due to the incomplete separation of coal from minerals by the separating technique at that time. Under aeration, this material can burn and will become red-colored and only slightly acid. The individual tailings differ by the size of the stones and the textural composition.

The extracted tailings come mostly from layers in great depth where no aeration and by this oxidation occurs. That means that the sulfur of the original organic matter from peat of the coal was transformed into sulfides. Iron sulfides occur. They are a dominant characteristic of mining spoil which influences essential the soil formation (Kerth, 1988; Burghardt, 1989a; Uzarowicz, 2011). Brought to the earth surface, the sulfide will oxidize and form sulfuric acid. The $\mathrm{pH}$ of the hard coal mining spoil will strongly decrease from originally a $\mathrm{pH}$ of around 7 or above, down to sometimes a pH of around 3 (Daniels and Zipper, 2018) which is too low for vegetation growth. The water of the swamps of peat formation was partly brackish. That means it was saline to some extent. Thus some coals, the salt coals, and their tailings are saline.

Another important influence on soil formation on hard coal mining tailings is the way of depositing the material. The techniques used changed with time. Old tailings were comparatively loosely deposited. Thus they were sensitive to spontaneous ignition. Younger tailings were thus compacted, and the surfaces bulldozed and leveled, which means without micro-relief, which would favor natural deposition of seeds, fine earth and water collection, and greening (Burghardt, 1989b).

\section{Material and methods}

The samples were taken from the greening trial of hard coal mining spoil in the city of Waltrop, Ruhr area, Germany (Fig. 1). The climate is moderately humid, with a mean annual temperature of $9.7^{\circ} \mathrm{C}$ (from 1980-2010) and a mean annual precipitation of $848 \mathrm{~mm}$ (Deutscher Wetterdienst, 2019). Investigated were mining spoils from two different mines of the region: Monopol mine and Achenbach mine. The deposited mine spoil was from recent mining. The spoils of both mines were deposed in a spoil heap which has the form of a long hill with a large plateau, designed as a landscape construction. On the plateau and the slopes, a field trial (Jochimsen, 1989) of 70 parcels with seven trial variants was established for studying soil greening processes. The trial includes different vegetation variants such as air born seeding which was dominated by birch tree seeds, seeding of a seed mixture Dauco-Melilotion community (Jochimsen, 1989), weak fertilizing, and three soil variants. The three soil variants concern pure tailings, a mixture of tailings with sandy loam 3:1, and a thin $(5 \mathrm{~cm})$ cover with sandy loam (Burghardt, 1989c; Braunersreuther and Burghardt, 2002; Burghardt and Niggemeyer, 2002). In the following, results of texture composition, of bulk density and pore volume, organic carbon content, sulfur content and $\mathrm{pH}$ from the soil trial variants, pure Monopol and Achenbach tailings, will be presented.

The investigations were performed on the pure tailing variants of Monopol and Achenbach mine spoil at the beginning and of tow time intervals, 8 years and 14 years after the establishment of the trial. The samples are for each sampling time and mine spoil from 6 parcels of the trial and four depths.

The samples were taken in early spring when the soil was moist from winter precipitation. The sampling was done two days after rainfall. The soil was saturated to field capacity. For gaining volume samples (Fig. 2), a metal ring of $32 \mathrm{~cm}$ diameter and $30 \mathrm{~cm}$ height was pushed $15 \mathrm{~cm}$ into the soil. For each sample 20 times the distance from soil surface to the top of the ring and the soil depth $2 \mathrm{~cm}, 5 \mathrm{~cm}$ and $10 \mathrm{~cm}$ was measured. For sampling 10 to $20 \mathrm{~cm}$ depth, a ring of $16 \mathrm{~cm}$ diameter was used. From the diameter and depth interval, the sample volume was calculated. From the weight of the dried sample, and the sample volume, the soil bulk density (volume weight) was calculated.

The texture fractions from fine earth $(<2 \mathrm{~mm})$ and gravel (2-6, 6-20, 20-60, > $60 \mathrm{~mm}$ diameter) were determined by sieving. The fine earth composition of the two soils from Monopol mine and Achenbach mine was described by Braunresreuther 
Fig. 1. Hard coal mining spoil greening trial Waltrop, Ruhr area, Germany, (A) past 3 years (Photo by W. Burghardt), (B) past 12 years (Photo by W. Burghardt)

Fig. 2. Scheme of procedure of volume sampling for bulk density determination of soils from hard coal mining spoil, (A) sampling rings $\emptyset 32 \mathrm{~cm}$ and $16 \mathrm{~cm}$ (Photo by W. Burghardt), (B) measuring depth of soil sample surface and bottom layer (Photo by W. Burghardt), (C) sampling arrangement
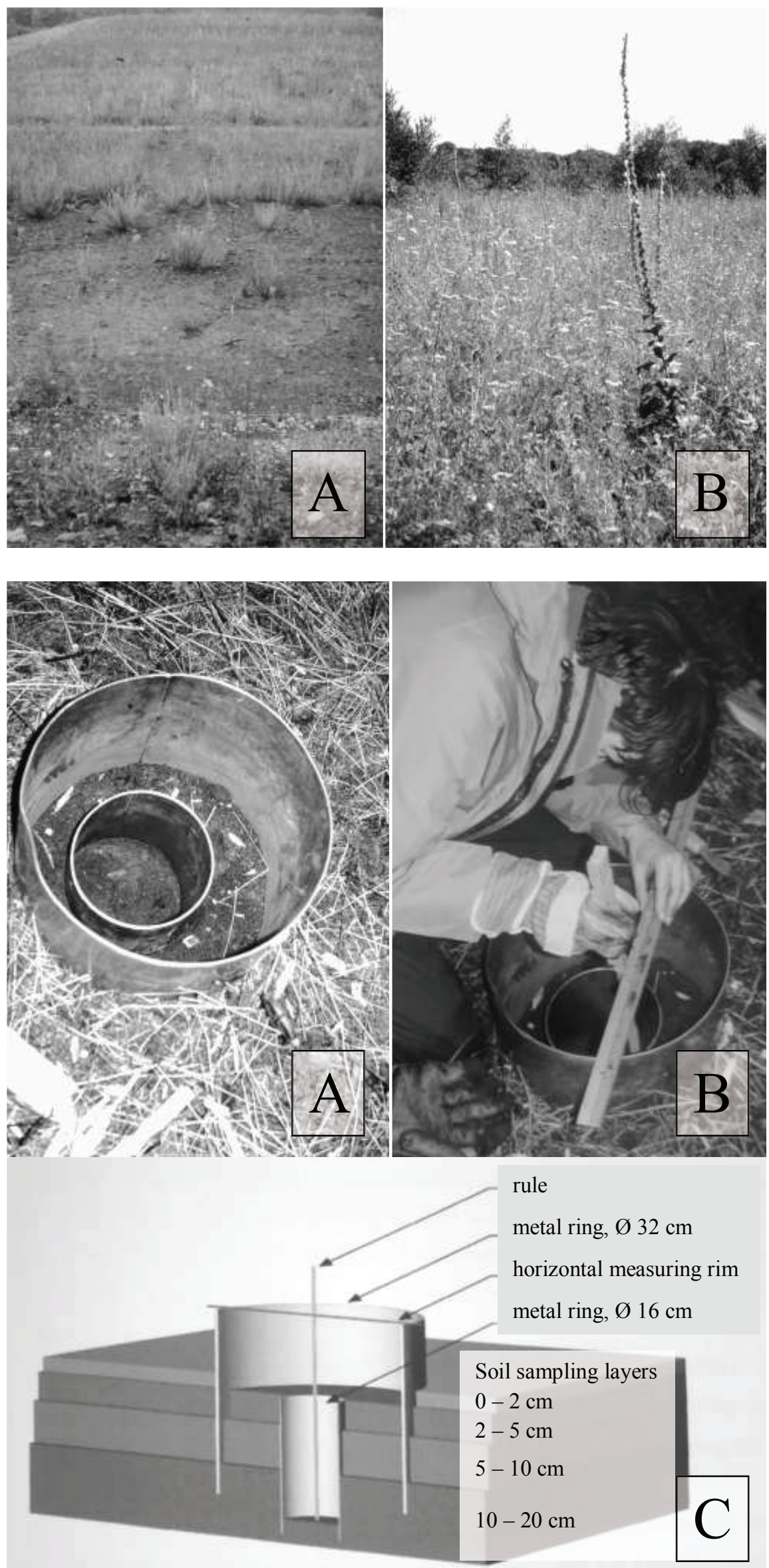


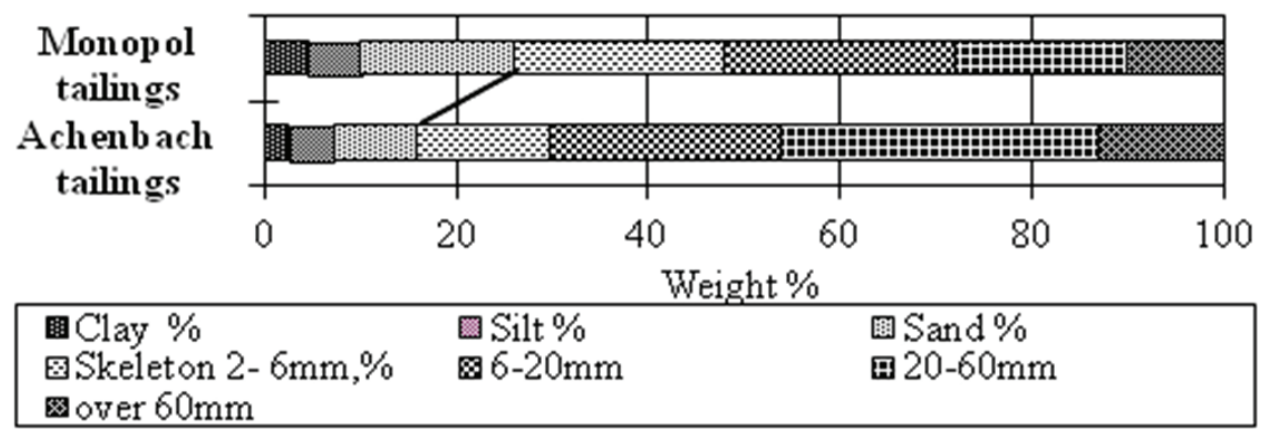

Fig. 3. Grain size distribution of fine earth and skeleton of Monopol and Achenbach mine spoil (Braunersreuther and Burghardt, 2002)

$$
\begin{aligned}
& \text { QSkeleton 2- } \\
& \text { खover } 60 \mathrm{~mm}
\end{aligned}
$$

and Burghardt (2002) (Fig. 3). The pH of the fine earth was measured in a $1: 2.5$ soil : $0.01 \mathrm{M} \mathrm{CaCl}_{2}$ dispersion. The total carbon and sulfur content was obtained with a Carlo Erba C-N-S analytical apparatus by gas chromatography.

The mine spoil contains inorganic carbon from hard coal. Thus the method to determine the organic carbon must be selective enough to measure primarily the organic carbon, and not parts of inorganic carbon. The traditional method to achieve this is the use of $\mathrm{H}_{2} \mathrm{O}_{2}$ (Jackson, 1958; Savage and Stevenson, 1961; Burghardt, 1989c). The method adds $25 \mathrm{ml}$ of $6 \% \mathrm{H}_{2} \mathrm{O}_{2}$ to $12 \mathrm{~g}$ fine earth. After 3 hours, the sample will be boiled down on the laboratory sand bath, and the sample weight will be determined again.

The results were classified as per table 1.

\section{Results}

\subsection{Skeleton content and volume of fine earth, skeleton and pores}

The main feature of hard coal mining spoil is the high content of skeleton from rock fragments which dominates the solid matter. It accounts for at least $50 \%$ of the solid matter. In the investigated four depth segments of the upper $20 \mathrm{~cm}$ of the hard coal mining spoil, the distribution of the content differs between the Monopol and Achenbach spoils (Fig. 4). Apart from in the depth of 0-2 cm, the skeleton content of Monopol spoil was lower than in the Achenbach spoil deposits. With increasing depth, the skeleton content stayed nearly constant in the Monopol spoil deposit. Different from this, the skeleton content of Achenbach spoil deposits increased significantly with depth continuously and was down from $2 \mathrm{~cm}$ higher than that of Monopol spoil. The results between the investigations after 8 and 14 years of establishment were about similar.
An insight into the structure of the hard coal mining spoil deposits gives the distribution of the volume of the different size classes of skeleton, of fine earth and of the pores within the spoil (Fig. 5). The fine earth volume was higher in the Monopol spoil as in the Achenbach spoil deposit. With increased depth, there was a slight increase of fine earth volume in the Monopol spoil but a slight decrease in the Achenbach spoil. The coarse skeleton fractions increased with depth. This was more expressed in the Achenbach spoil than in the Monopol spoil. The pore volume of both spoils decreased very strongly with depth from over $60 \%$ to less than 50\%. This was more expressed in the Achenbach spoil than in the Monopol spoil. The spread of pore volume decrease in the Monopol spoil was about 17 and 20 vol. \%, and Achenbach spoil was 30 and 35 vol. \%, after 8 and 14 years, respectively, after trial establishment.

\subsection{Bulk density of the deposited spoil}

The bulk density (volume weight) of the different spoils generated by the fractions fine earth and skeleton varied between very low to low (1200 $\left.\mathrm{mg} \mathrm{cm}^{-3}\right)$ and very high (>1800 $\left.\mathrm{mg} \mathrm{cm}^{-3}\right)$ values (Tab. 1). The bulk density increased distinctly with depth from low to very high for the Monopol spoil and from very low to high for the Achenbach spoil (Tab. 1, Fig. 6).

The contribution of skeleton fraction to the bulk density is higher than of the fine earth fraction. The contribution of skeleton fraction increased distinctly with depth in both spoil variants and sample times. The contribution of fine earth fraction to the bulk density of Monopol spoil was overall, in depth and sampling times, about the same and down from $2 \mathrm{~cm}$ higher than in the Achenbach spoil. In the Achenbach spoil, the contribution of fine earth fraction decreased strongly with depth.

A close relationship between bulk density of skeleton fraction to the fine earth fraction would indicate a weathering of skeleton

\section{Table 1}

Classification of bulk density and soil organic carbon (STOC) content and stock (Burghardt and Schneider, 2016, improved)

\footnotetext{
1) Arbeitsgruppe Boden (2005)

2) Calculation of the TOC density from the regression equation: TOC density $=-0.59 \mathrm{TOC}^{2}+14.39 \mathrm{TOC}+0.5 ; \mathrm{R}^{2}=0.84 ; \mathrm{n}=83$;
}

\begin{tabular}{llll}
\hline Category & $\begin{array}{l}\text { Bulk density } \\
\mathrm{g} \mathrm{cm}^{-3}\end{array}$ & $\begin{array}{l}\text { TOC-content } \\
\%\end{array}$ & $\begin{array}{l}\text { TOC-stock } \\
\mathrm{kg} \mathrm{m}^{2}\end{array}$ \\
\hline Very low & $<1.20$ & 0.6 & $<2$ \\
Low & $1.20-1.40$ & $0.6-1.2$ & $2-4$ \\
Moderate & $1.40-1.60$ & $1.2-2.4$ & $4-8$ \\
High & $1.60-1.80$ & $2.4-4.8$ & $8-16$ \\
Very high & $>1.80$ & $4.8-8.7$ & $16-24$ \\
Extreme high & & $>8.7$ & $>24$ \\
\hline
\end{tabular}




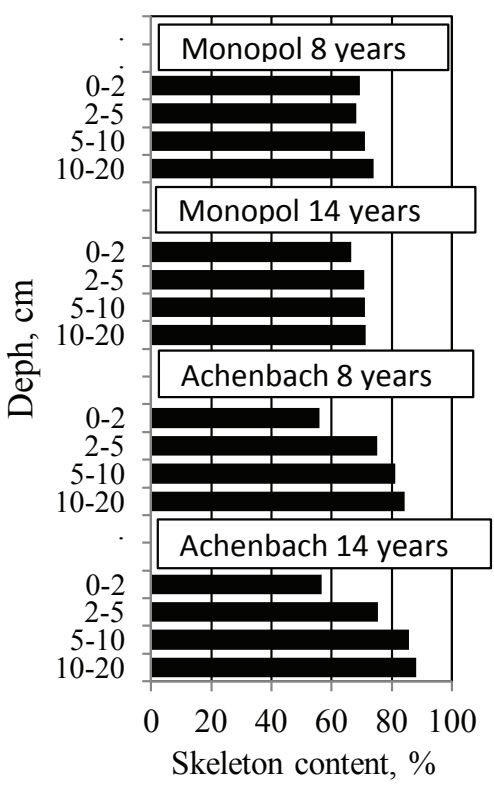

Fig. 4. Distribution with depth of skeleton (stone) contents of the hard coal mining spoil greening variants Monopol and Achenbach spoil of the field trial Waltrop, 8 and 14 years past the trial establishment

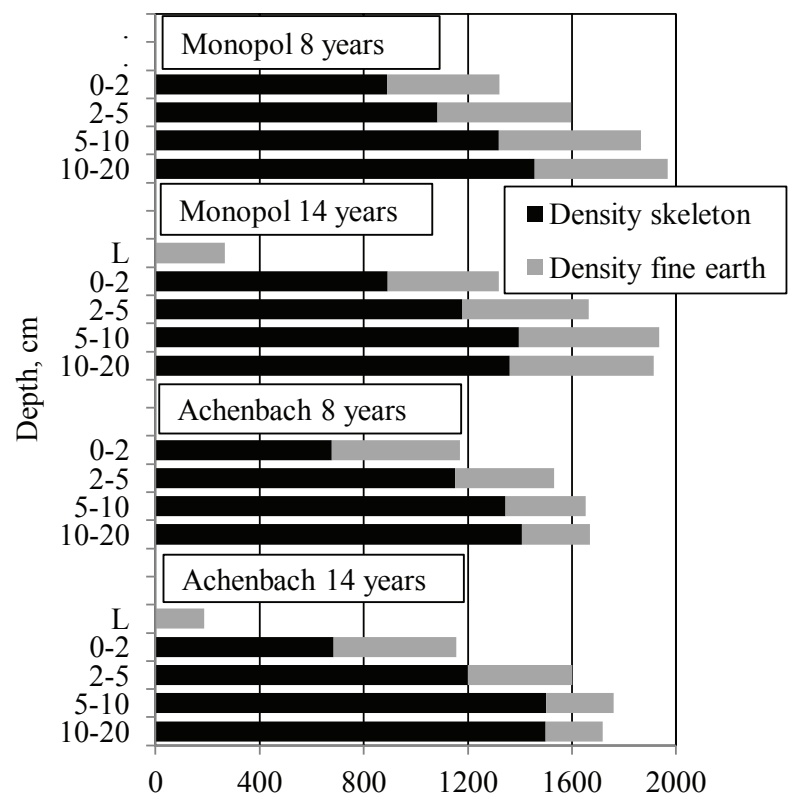

Sum skeleton and fine earth density, $\mathrm{mg} \mathrm{cm}^{-3}$

Fig. 6. Distribution with increasing depth of the bulk density (volume weight) and its density of skeleton and fine earth fraction of the hard coal mining spoil greening variants Monopol and Achenbach spoils of the field trial in Waltrop, 8 and 14 years past the trial establishment

from rock fragments. In the Monopol spoil this was not existing, but a close one was determined for the Achenbach spoil (Fig. 8).

After 14 years of the trial, litter (L) did form on the spoil surface. The bulk density of the litter was about $200 \mathrm{mg} \mathrm{cm}^{-3}$, and for the Achenbach spoil was slightly lower than for the Monopol spoil (Fig. 6).

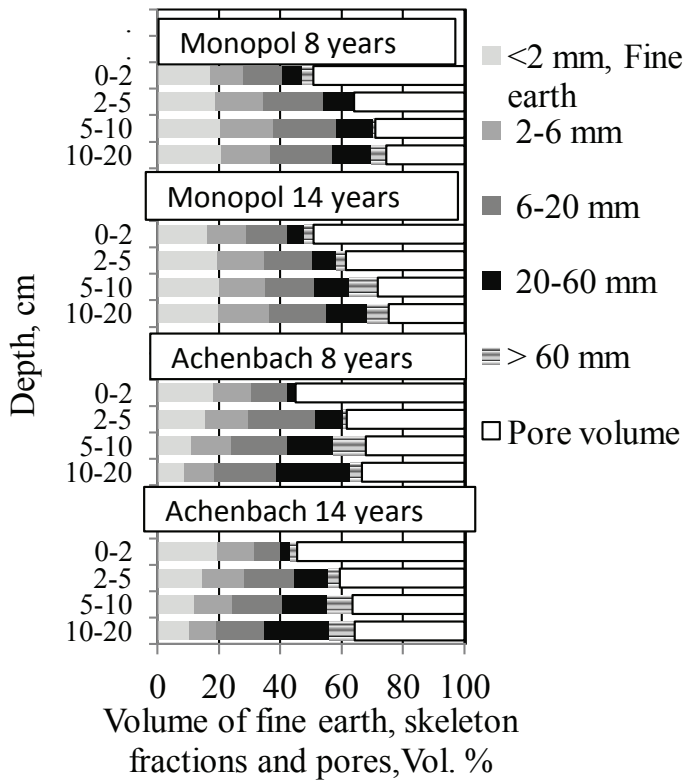

Fig. 5. Distribution with increasing depth of the volume of fine earth $(<2$ $\mathrm{mm}$ ), of skeleton fractions 2-6, 6-20, 20-60, > $60 \mathrm{~mm}$ diameter and pore volume of the hard coal mining spoil greening variants Monopol and Achenbach spoils of the field trial in Waltrop, 8 and 14 years past the trial establishment

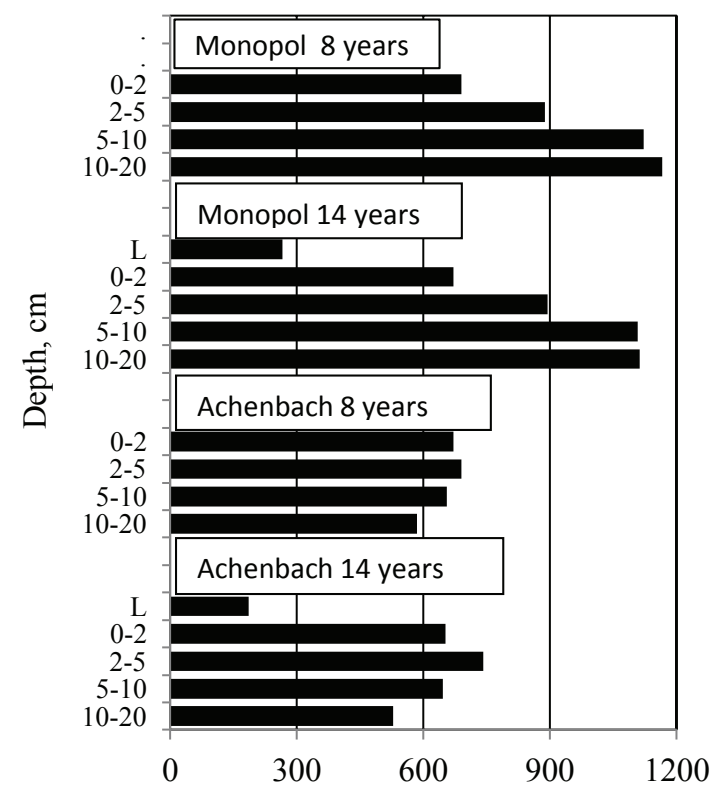

Density of stone free fine earth, $\mathrm{mg} \mathrm{cm}^{-3}$

Fig. 7. Distribution with increasing depth of the bulk density of the fine earth in the spaces between the stones of the hard coal mining spoil greening variants Monopol and Achenbach spoils of the field trial in Waltrop, 8 and 14 years past the trial establishment

The fine earth material will fill the void volume between the gravel and stones which form the skeleton. Thus the density of fine earth filling related to the volume between stones was calculated. The bulk density of fine earth in the voids between stones is very low (between 500 and $1200 \mathrm{mg} \mathrm{cm}^{-3}$; Tab. 1). The bulk density of fine earth between stones is lower in the Achen- 
Fig. 8. Correlation of the bulk density of fine earth fractions and the bulk density of skeleton fractions of the hard coal mining spoil Monopol and Achenbach

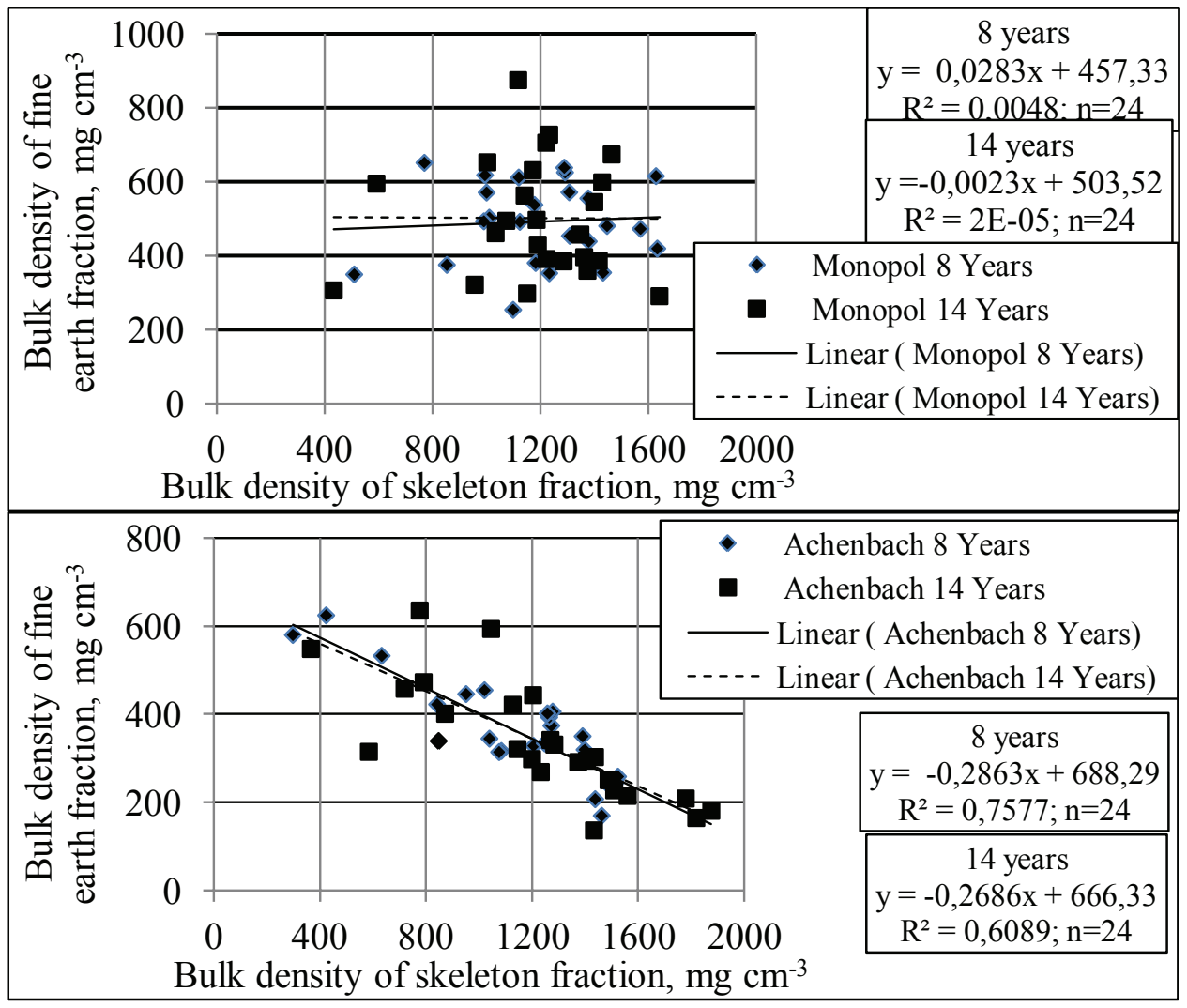

bach spoil than in the Monopol spoil (Fig. 7). The bulk density of the fine earth in the spaces between the stones increased with depth in the Monopol spoil. In the Achenbach spoil, there was primarily a decreasing trend. For both sampling times of 8 and 14 years after trial establishment, the results of bulk density of fine earth between stones are about similar.

\subsection{Inorganic and organic carbon content and stock}

The sum of inorganic and organic carbon content from coal and of the organic carbon content of humic substances in the Monopol spoil was between 100 and $150 \mathrm{mg} \mathrm{g}^{-1}$ and in the Achenbach spoil was between 50 and $190 \mathrm{mg} \mathrm{g}^{-1}$. The increase with depth was low in the Monopol spoil, and high in the Achenbach spoil (Fig. 9).

In the hard coal mining spoil of both trial variants, Monopol and Achenbach spoils, within eight years, a marked accumulation of TOC occurred in the fine earth (Fig. 10). This main feature of soil development was present in all trial variants. But it differed significantly between the two mining spoil variants. Eight years after the trial start, in the top $2 \mathrm{~cm}$ of Monopol spoil, the TOC content of fine earth was already moderate (Tab. 1). It decreased gradually from $0-2$ to $10-20 \mathrm{~cm}$ depth and then to low values. After 14 years, the TOC content was also in the $2-5 \mathrm{~cm}$ depth moderate.

In contrast to this pattern, the TOC contents of fine earth in the Achenbach spoil was low (Tab. 1) in all investigated depth segments after eight years of soil development. The TOC content was nearly uniform over the total depth of $0-20 \mathrm{~cm}$ and thus did not show the strong decrease of the Monopol mining spoil. After 14 years, the TOC increased in the top $0-2 \mathrm{~cm}$ to moderate contents. Also in the depth segment 2-20 cm, an increase of TOC was distinctly determinable, but it stayed nearly uniform low with depth.

In most soils the accumulation of TOC will have an influence on fine earth bulk density. Fig. 14 shows a close relationship between TOC content and bulk density of the Monopol samples, which decreased slightly with time in 14 years. The correlation for the Achenbach spoil after 8 years was weak and increased strongly with time. The results indicate differences for intrusion of organic carbon rich fine earth which occurred in Monopol spoil earlier than in Achenbach spoil.

The stock of TOC which accumulated in 8 and 14 years was in both mining spoils very low (Tab. 1). The TOC stock was 0.98 and $1.0 \mathrm{~kg}$ TOC $\mathrm{m}^{-2}$ in $0-20 \mathrm{~cm}$ depth of the Monopol spoil after 8 years and 14 years, respectively (Fig. 11). In the Achenbach spoil, the TOC stock was much lower and achieved 0.56 and 0.65 $\mathrm{kg} \mathrm{TOC} \mathrm{m}^{-2}$ in $0-20 \mathrm{~cm}$ depth.

\subsection{Sulfur content and $\mathrm{pH}$}

The sulfur content differed between the two mining spoils, Monopol and Achenbach (Fig. 12). The sulfur content was in the fine earth of Monopol spoil in the top $2 \mathrm{~cm} 2.0 \mathrm{mg} \mathrm{g}^{-1}$, and the Achenbach spoil $3.7 \mathrm{mg} \mathrm{g}^{-1}$ in the 8 years samples. The sulfur content decreased to $1.4 \mathrm{mg} \mathrm{g}^{-1}$ in the Monopol spoil and $1.9 \mathrm{mg}$ $\mathrm{g}^{-1}$ in the Achenbach spoil in the 14 years samples. With increasing depth, the sulfur content increased in the fine earth of Mo- 


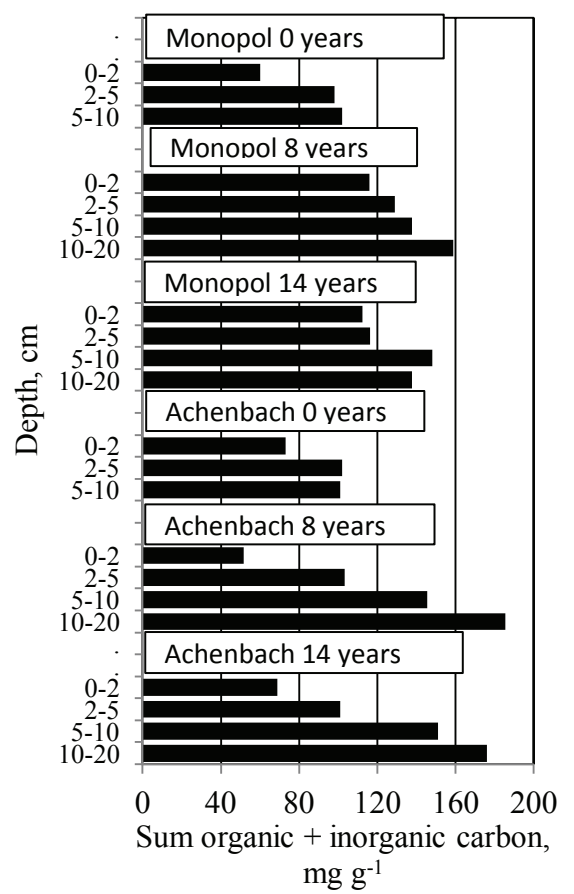

Fig. 9. Distribution with increasing depth of the sum of the inorganic and organic carbon content of the fine earth of the hard coal mining spoil greening variants Monopol and Achenbach spoils of the field trial in Waltrop, 8 and 14 years past the trial establishment

Fig. 11. Cumulative depth curve of the organic carbon (TOC) stock from 0-20 cm depth of the fine earth of the hard coal mining spoil greening variants Monopol and Achenbach spoils of the field trial Waltrop, 8 and 14 years past the trial establishment

nopol spoil only slightly to 3.3 and $2.2 \mathrm{mg} \mathrm{g}^{-1}$ in $10-20 \mathrm{~cm}$ depth in the samples taken after 8 and 14 years, respectively. For the Achenbach spoil, the contents strongly increased with depth to 10.9 and $7.7 \mathrm{mg} \mathrm{g}^{-1}$, respectively. The results of both spoils indicate a decrease of sulfur content in the top soil with time.

Past 14 years, at sites of both spoil variants, a litter layer was already formed by the vegetation. The organic material of the litter also contained sulfur (Fig. 12). With $1.3 \mathrm{mg} \mathrm{g}^{-1}$, the sulfur content was in the Monopol spoil variants lower than in the Achenbach variants with $2.1 \mathrm{mg} \mathrm{g}^{-1}$. In both trial variants, the sulfur content in the litter was in the range of the sulfur content of the fine earth in 0-2 cm depth.

The sulfur occurs in the mining spoil as Pyrite and Marcasite. These sulfides will, with the mining spoil, come into contact with air and oxidize to sulfuric acid. This process lowered the $\mathrm{pH}$ value which was measured in the fine earth fraction of the

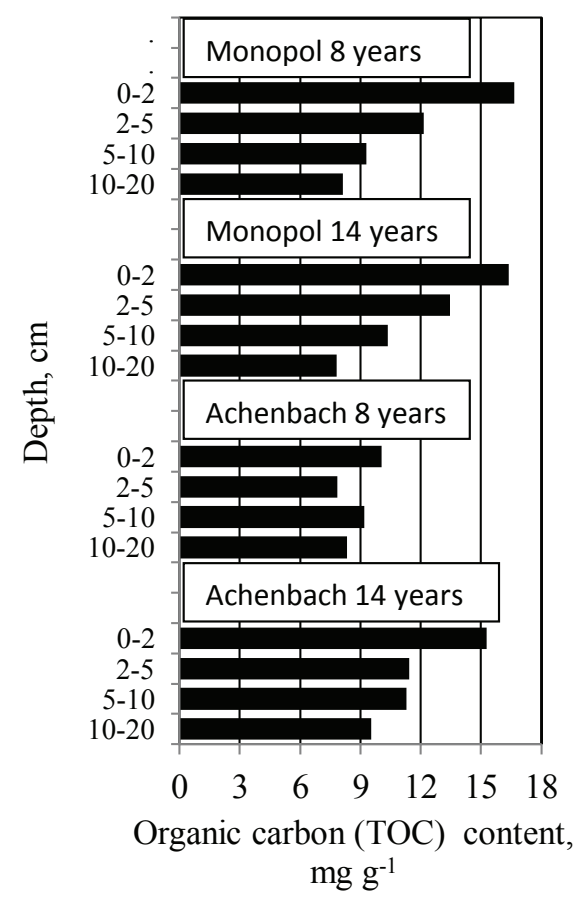

Fig. 10. Distribution with increasing depth of the organic carbon (TOC) content of the fine earth of the hard coal mining spoil greening variants Monopol and Achenbach spoils of the field trial in Waltrop, 8 and 14 years past the trial establishment

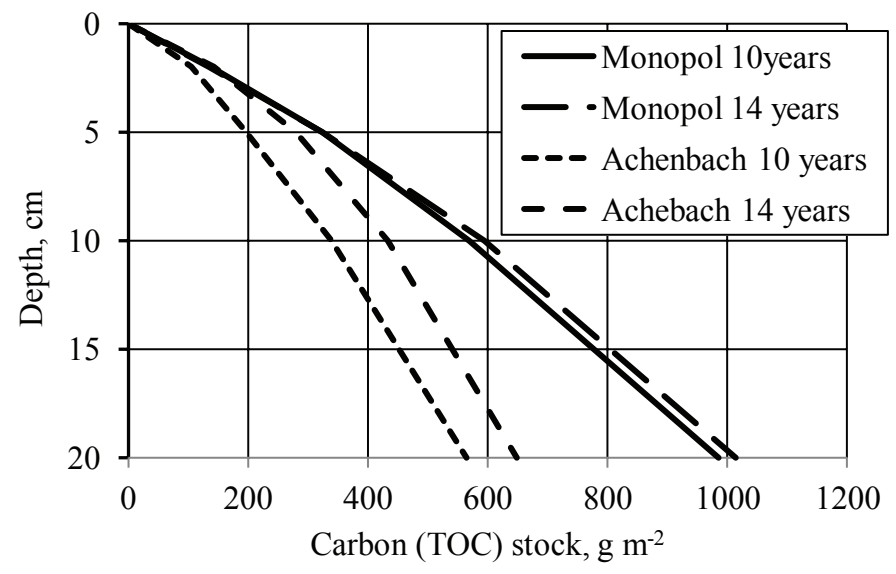

spoils. At the time of establishing the field trial in Waltrop, the $\mathrm{pH}$ of the fine earth of both Monopol and Achenbach spoils was pH 7.6 - i.e. very weakly alkaline (Burghardt, 1989c). In the Monopol spoil it decreased after 8 years to a slightly acidic value of pH 5.6 and after 14 years to 5.2 in the top $0-2 \mathrm{~cm}$ layer and increased with depth strongly to neutral values of $\mathrm{pH} 7.2$ after 8 and 14 years (Fig. 13).

The results of the Achenbach spoil were totally different from the Monopol spoil. The Achenbach spoil had in its $0-2 \mathrm{~cm}$ depth, after 8 years, a pH value of 4.2 which raised to $\mathrm{pH} 4.6$ in the 14 year old spoil. Until the depth of $20 \mathrm{~cm}$, the pH stayed nearly unchanged and achieved values of $\mathrm{pH} 4.5$ and 4.4 after 8 and 14 years trial time, respectively. Thus the fine earth fraction of the Achenbach spoil was strong acid over all investigated depth intervals. But after 14 years the $\mathrm{pH}$ showed a slight increase in $0-10 \mathrm{~cm}$ depth. 


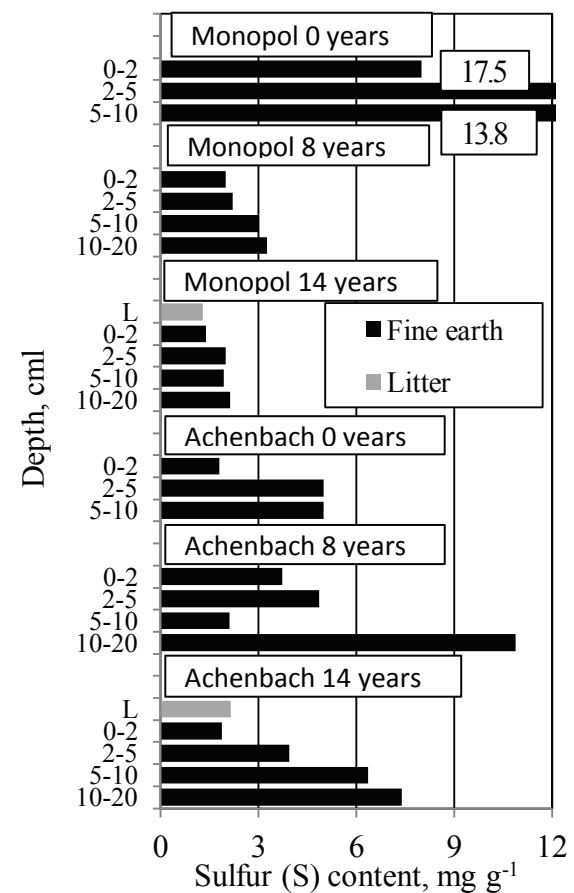

Fig. 12. Depth distribution of sulfur content of the fine earth of the hard coal mining spoil greening variants Monopol and Achenbach spoils of the field trial in Waltrop, 8 and 14 years past the trial establishment

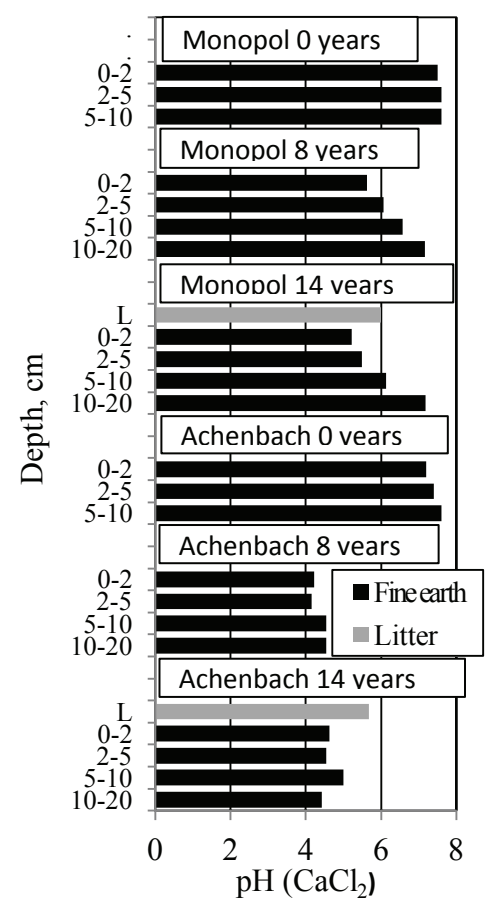

Fig. 13. Depth distribution of the $\mathrm{pH}\left(\mathrm{CaCl}_{2}\right)$ of the fine earth of the hard coal mining spoil greening variants Monopol and Achenbach spoils of the field trial in Waltrop, 8 and 14 years past the trial establishment
Fig. 14. Correlation of bulk density and of organic carbon (TOC) content of the hard coal mining spoils Monopol and Achenbach
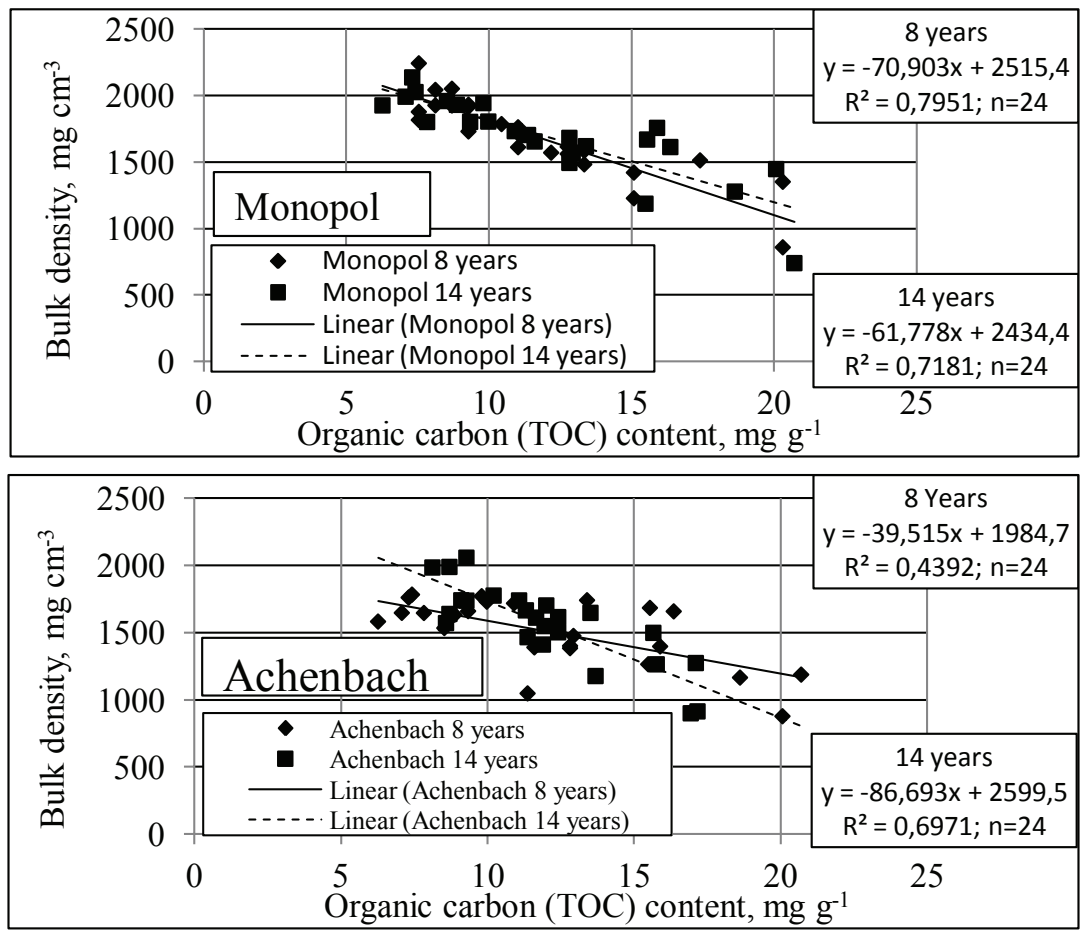

Besides these differences of $\mathrm{pH}$ level and depth distribution between the two mine spoils, there were differences in the dependence of $\mathrm{pH}$ from the pore volume of the soil samples (Fig. 15). The pH decreased with an increased pore volume of Monopol spoil in both sampling times 8 and 14 years after the trial started. For the Achenbach spoil, this relationship was not ob- served. The distribution of pore volume with depth was for both spoils and sampling times nearly the same. Different was the increased density of stone-free fine earth, and the higher organic carbon content of the Monopol spoil.

After 14 years of the field trial, the $\mathrm{pH}$ in the litter was 6.0 in the Monopol spoil, and 5.7 in the Achenbach spoil (Fig. 13). 
Fig. 15. Correlation of $\mathrm{pH}$ to pore volume of the hard coal mining spoil variants Monopol and Achenbach

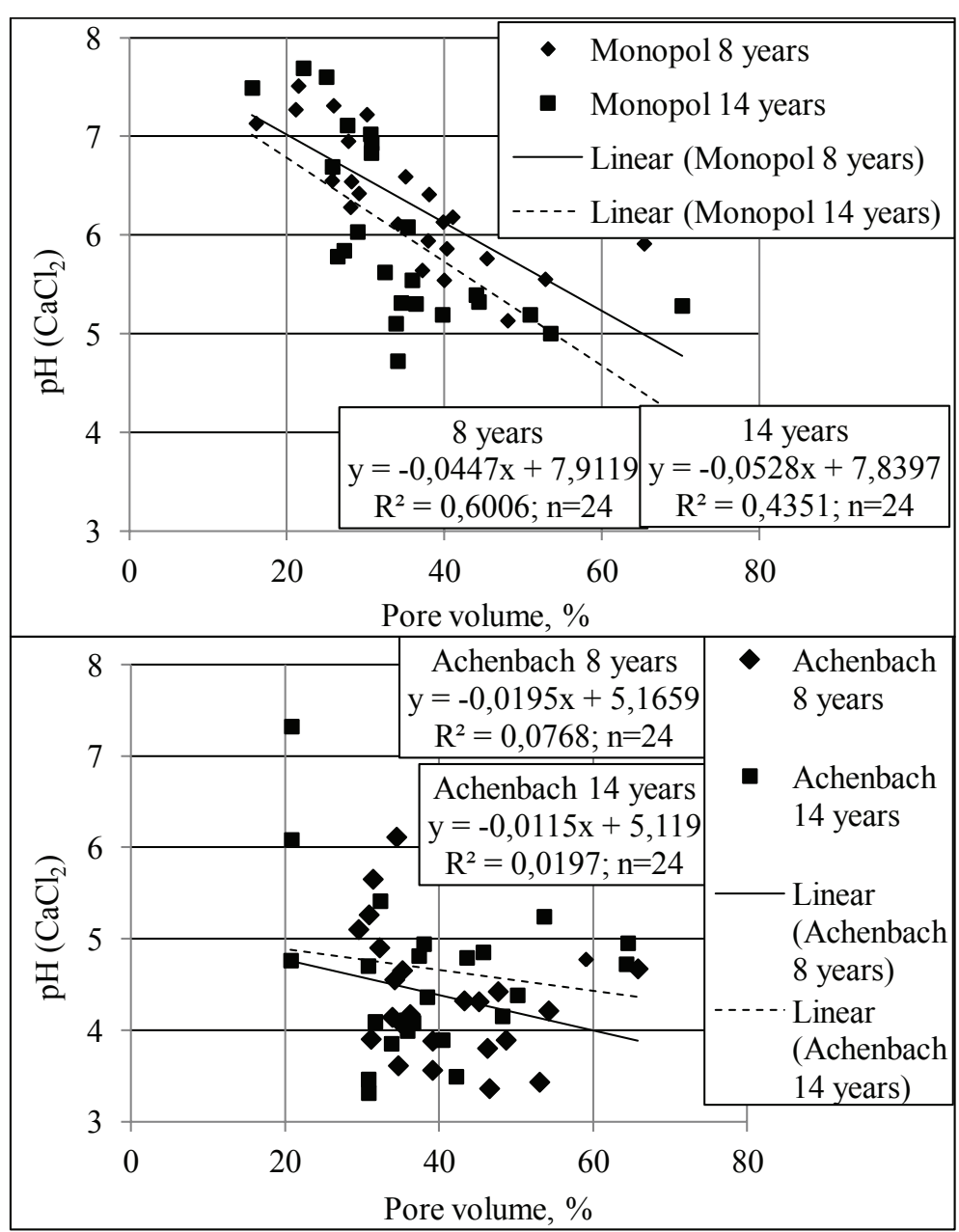

That means the $\mathrm{pH}$ values of the litter were slightly acidic and about 1 step higher than in the following mine spoil layer in 0-2 cm depth.

\section{Discussion}

The effect of stones in soils on the reduction of soil fertility has been described by Rytter, (2012). Similarly, the change of soil cover of the mining area of Ruhr from silty loam without stones to soils dominated by stones from rock fragments, shifts the soil properties of the region from soil of high fertility farmland (Burghardt et al., 2018) to soil of extremely low fertility. The productive fine earth is now buried under mine spoil. Within the stony mine spoil (Haering et al., 2004; Kompała-Bąba et al., 2019), the content of productive fine earth content is low. Thus the capacity of soils from hard coal mining spoil to store organic carbon, water and plant nutrients is limited.

The landscape from hard coal mining spoil heaps has the character of a mountainous region. The deposited material is from broken and not weathered rocks. As with all surface materials, the fresh mining spoil is subject to soil forming processes by weathering, humus accumulation and water and wind erosion. This way, with time, the new soils of mining spoil will bring back some low fertility to the area and by this small capacity to fulfill diverse ecological soil functions (Morel et al., 2014).

Stony soils are generated from rocks initially by physical and then by chemical and biological weathering. Stony soils will also develop on fragments of rock fall, and on glacial and fluvial gravel deposits. The hard coal mining spoil bears some resemblance to rock falls according to its edged shape and the fluvial gravel deposits according to its stone size sorting. Besides this, by its geological formation, the hard coal mine spoil has the shape of shale. The shale stones are small when derived from silt and clay sediments, and coarse when derived from sand sediments.

The obtained results show large differences between the two investigated spoils from Monopol and Achenbach mines. The differences concern rock size composition, fine earth content, bulk density, pore volume, TOC and sulfur content, $\mathrm{pH}$, and the distribution of these properties in the investigated soil depth segments, $0-2$, 2-5, 5-10 and 10-20 cm. The differences were observed in both sampling times, 8 and 14 years after the field trial was set up.

The skeleton content in the Monopol spoil at all depth segments is nearly equal to $70 \%$ per weight at all investigation times. In the Achenbach spoil, the skeleton content increased with depth steadily from 56 to 86 and $88 \%$ from the start of the 
field trial to 8 and 14 years past start (Fig. 4). This distribution picture changes distinctly when the results are related to the soil volume (Fig. 5). The bulk density of the skeleton (Fig. 6) of both Monopol and Achenbach spoils increased with depth from about 890 and $680 \mathrm{mg} \mathrm{cm}^{-3}$, respectively in 0-2 $\mathrm{cm}$ depth, to about 1460 and $1360 \mathrm{mg} \mathrm{cm}^{-3}$ past 8 and 14 years in the Monopol spoil, respectively 1410 and $1500 \mathrm{mg} \mathrm{cm}^{-3}$ in the Achenbach spoil.

The differences of both spoil variants for the fine earth bulk density are stronger (Fig. 6). They increased with depth from about 430 to $510 / 560 \mathrm{mg} \mathrm{cm}^{-3}$ in the Monopol spoil and decreased from $490 / 470$ to $260 / 220 \mathrm{mg} \mathrm{cm}^{-3}$ in the Achenbach spoil. The differences between Monopol and Achenbach spoils are more considerable when the fine earth content is related to the volume between stones (Fig. 7). It increases in the Monopol spoil from more than 660 to more than $1100 \mathrm{mg} \mathrm{cm}^{-3}$, and stayed around 550 to $750 \mathrm{mg} \mathrm{cm}^{3}$ in the Achenbach spoil.

The question is what are the reasons for the differences of fine earth contents and its distribution with increasing depth of the Monopol and Achenbach spoil? Perhaps the answer lies in the organic carbon distribution. The results show a close relationship between TOC content and bulk density of the Monopol samples (Fig. 14). For the Achenbach spoil after 8 years the relationship was weak and increased strongly with time. Thus one can assume that in the early phase of soil development of Monopol spoil, the conditions for intrusion of TOC rich fine earth was given. However, in the Achenbach spoil, the TOC accumulation started later.

Beside the intrusion of organic carbon rich fine earth one can assume a second soil forming factor. The lack of relationship between bulk density of skeleton fraction to the fine earth fraction (Fig. 8) in the Monopol spoil, but a close one for the Achenbach spoil would mean that the mine spoil weathering as a source of fine earth is in the Monopol spoil not a main factor, but it is an important factor for the Achenbach spoil. Late starting TOC accumulation in the Achenbach spoil, let us assume that bioturbation produced the accumulation. In contrast, the intrusion of fine earth plays a dominant role in the soil formation of Monopol soil from the beginning. The two mine spoils seem to represent two different ways of soil formation of stony substrates.

The accumulation of TOC differed between both spoils. Within $20 \mathrm{~cm}$ in the Monopol spoil, it was about $1 \mathrm{~kg} \mathrm{~m}^{-2}$, and $0.6 \mathrm{~kg} \mathrm{~m}^{-2}$ in the Achenbach spoil (Fig. 11). It increased over the period of 8 years to 14 years after the mine spoil deposition by 0.03 and $0.08 \mathrm{~kg} \mathrm{~m}^{-2}$. This indicates that the process of soil formation by TOC accumulation within the spoil has nearly finished within 8 years. This means the observed soil development occurred within few years. The formation of an Ah horizon was fast. Similarly, Hearing et al. (2004) reported about Appalachian coal mine soils a development of soils within few years.

How the fast formation of an Ah horizon could occur? The accumulated content of TOC of about $10 \mathrm{mg} \mathrm{g}^{-1}$ (Fig. 10) in fine earth was in the mining spoil about in the same level as in arable land of the region. However, the fine earth volume of mine spoil was only about $20 \%$ (Fig. 5) and not $100 \%$ as in arable land. That means that a fast accumulation of TOC in the mine spoil oc- curred due to the low fine earth volume. For the sufficient supply of TCO one can assume that the availability of high amounts of litter from the herbaceous mixture of Dauco-Melilotion community seeding (Jochimsen, 1989, 1996, 2001) was essential.

The TOC accumulated in the total top soil of mine spoil was far below that of the farmland on natural soils of the region which achieves 12 to $14 \mathrm{~kg} \mathrm{~m}^{2}$ within $1 \mathrm{~m}$ depth (Burghardt et al., 2018). Thus, hard coal mine spoil landscapes have extremely poor storage capacities for TOC (Fig. 11).

Studies on soil development of hard coal mining spoil are mostly devoted to the content of sulfur compounds Pyrite and Marcasite which developed under reducing conditions in the deep mine environment. These sulfides will oxidize when brought into contact with the atmosphere. The developing sulfuric acid strongly decreases the pH of the soil (Kerth, 1988; Hackelberg et al., 1995; Maiti and Ghose, 2005; Uzarowicz, 2011). Compared to the Achenbach spoil, the sulfur content in the Monopol spoil was high at the start of the field trial but strongly decreased within 8 years in all depths (Fig. 12). In contrast, the sulfur content stayed high in the Achenbach spoil and increased with depth. The pH in the Monopol spoil only lowered to 5.6/5.2 at $0-2 \mathrm{~cm}$ depth after 8 and 14 years, respectively and increased with depth to $\mathrm{pH}$ 7. The $\mathrm{pH}$ values of Achenbach were much lower and stayed between 4.2 and 4.6, and 4.4 and 5.0, respectively after 8 and 14 years of the field trial.

The difference of $\mathrm{pH}$ distribution in both spoils (Fig. 13) can be explained by the increased density of stone-free fine earth (Fig. 7), and lowered pore volume (Fig. 5, 15), and the higher TOC of the Monopol spoil compared to Achenbach spoil (Fig. 10). One can assume that the low pore volume and the reduction capacity of organic matter hinder the oxidation of sulfides and thus cause no strong decrease in the $\mathrm{pH}$ of Monopol spoil. The effect of organic matter of diminishing the oxidation potential of soils is also known from other soils (Sabiene et al., 2010). The higher $\mathrm{pH}$ due to higher TOC content will favor plant growth and success of hard coal mining spoil reclamation (Daniels and Zipper, 2018).

Some special methods were used in the investigation of soil properties. To record the soil development, repeated sampling after several years should be undertaken. The sampling 0,8 and 14 years after the deposition of the hard coal mining spoil showed that already in the first 8 years most of the soil development processes took place. The very differentiated depth segmentation of sampling in 0-2, 2-5, 5-10 and 10-20 cm depth permitted capture detailed the soil forming processes which start at the soil surface.

The content of TOC was determined by the use of $\mathrm{H}_{2} \mathrm{O}_{2}$ as an agent to destroy humic substances generated during soil formation (Jackson 1958). The organic carbon content strongly influences the bulk density and the exchange capacity of soils. The correlation coefficients gained for the relationship between the bulk density and TOC content (Monopol 8 years: $\mathrm{R}^{2}=0.80$, Monopol 14 years: $\mathrm{R}^{2}=0.72$; Achenbach 8 years: $\mathrm{R}^{2}=0.44$; Achenbach 14 years: $R^{2}=0.70$; for each of them: $n=24$; old spoil heap $>30$ years: $R^{2}=0.85, n=15$ ), and between the exchange capacity and TOC content of fine earth $\left(R^{2}=0.75, n=116\right)$ indicate that the method captured the organic carbon.

The achieved TOC content of at least $6 \mathrm{mg} \mathrm{g}^{-1}$ in all inves- 
tigated depths to $20 \mathrm{~cm}$ below the surface and spoil variants within 8 years characterizes this depth segment as an Ah horizon. The mining spoils had a high stone content. The volume of stones in the spoils was between 40 and 60 Vol. \% in $2-20 \mathrm{~cm}$ depth, and in 0-2 cm depth 27-28 Vol. \%. Thus the soils can be designated as Skeletic. The volume of fine earth is between 8 and $20 \%$. This indicates Leptic properties. The mine spoil substrate is Spolic and thus can be characterized as Technic. As additional important characteristics, the high sulfur content and fine earth intrusion should be considered as Sulfuric and Intrusic.

In the soil classification of Germany (Arbeitsgruppe Boden, 2005) the soils developed on mining spoil are designated as Regosols from hard coal mining spoil substrate. Within US Soil Taxonomy, the soils would belong to the Entisols (Bockheim et al., 2014). The soil classification of the ISSS Working Group WRB (IUSS Working Group WRB, 2015) would position them due to the fine earth content of less than $20 \%$ to the Leptosols, with the qualifiers Technic, Skeletic and as additional qualifiers, Sulfuric and for Monopol spoil type Intrusic. Alternative, designations could include classifying the soils as Spolic, Skeletic, Sulfuric, Intrusic (for Monopol spoil type only) Technosols on the basis of WRB classification.

\section{Conclusions}

Soil formation rapidly takes place in stony substrates of the hard coal mining spoil, in the investigated examples within 8 years. Reasons are the low fine earth content and the accessibility of pore volume between stones. The results show that strong differences exist between mining spoils of different origin. The differences particularly concern the stone content and bulk density of the stone and fine earth fraction, and the depth distribution of these features.

The process of soil formation was not uniform between the two investigated mining spoils. One could distinguish two types of soil formation on stony substrate. In the Monopol spoil, one can assume that the soil formation was dominated by the intrusion of organic matter containing fine earth into the pores between stones. In the Achenbach spoil, weathering of mine stones was the source of fine earth, and organic matter was mixed into the fine earth later perhaps by turbation.

The different soil formation processes result in different amounts of TOC accumulation. The TOC accumulation was within 8 and 14 years with $1 \mathrm{~kg} \mathrm{~m}^{-2}$ significant higher in the soils from Monopol mine spoil than with $0.6 \mathrm{~kg} \mathrm{~m}^{-2}$ from Achenbach mine spoil. The $\mathrm{pH}$ drop with time due to oxidation of sulfides to sulfuric acid was not uniform between both mining spoils. The pH significantly increased with depth in the Monopol mining spoil to neutral values. In the Achenbach spoil, it dropped uniformly to values around pH 4 within 8 and 14 years. In the Monopol mining spoil, an influence of pore volume of the soil occurred. A higher pore volume resulted in a lower $\mathrm{pH}$. Such a correlation did not occur in the Achenbach soil.

Soil formation and development of soil properties can be very diverse in mining spoil. The results show that mining spoil can have very different properties for vegetation growth. Before starting reclamation and greening projects, the mine spoil properties should be carefully investigated.

The bringing up to the surface of stony spoil from hard coal deep mining causes the landscape to lose its original soil quality. This is particularly the case for the hard coal mining regions from Eastern France and Belgium, via the Ruhr area and southern Poland to Ukraine which natural and farmland areas are from the world most fertile loamy silt soils which developed on loess. The valuable capacities of these soils to store TOC and water, and to produce food and mitigate the climate are lost.

On the other hand soils from hard coal mining spoil can be interesting habitats for vegetation and fauna. The hard coal mining spoil has characteristics of soils of mountain regions. Thus vegetation and fauna of the soils from hard coal mining spoil differ from the original stone free soils from silt loam of the region. The seeding of a seed mixture of Dauco-Melilotion community (Jochimsen, 1989) from mountainous regions supported the establishment of new habitats on the soils of the hard coal mining spoil of the field trial Waltrop. This way the diversity of vegetation and fauna of the region is improved. (Weiss et al., 2005). Particular stony soils from hard coal mining spoil have a high bio-diversity (Woch et al., 2013; KompałaBąba et al., 2019). In the present situation, this can be an interesting aspect of the evaluation of mining spoil areas because rural landscapes have become impoverished of plant and animal species. Efforts of investigation of nature and biodiversity of hard coal mining spoil started in the German Federal State North Rhine-Westphalia in the Ruhr area by the project Industriewald - Urban Industrial Woodlands (Weiss et al., 2005). The meaning of the determined differences of the properties of individual mining spoils like Monopol spoil and Achenbach spoil of the field trial Waltrop for the local bio-diversity is until now not known.

\section{Acknowledgement}

The project was initiated by the Ruhrkohle Bergbau-AG, Herne and the Kommunalverband Ruhrgebiet, Essen. Financial support was given by the Ruhrkohle Bergbau-AG. The City of Waltrop accepted and promoted the long time field trial in one of its most visited recreation areas. The authors thank them for giving the facility to accomplish the presented study. The authors thank also the SOIL SCIENCE ANNUAL for publishing the investigations on hard coal mining spoil, and the editor and reviewers for their support to improve essentialy the paper.

\section{References}

Alves Dias, P., et al., 2018. EU coal regions: opportunities and challenges ahead, EUR 29292 EN, Publications Office of the European Union, Luxembourg, 2018, ISBN 978-92-79-89884-6. https://doi. org/10.2760/064809, JRC112593

Arbeitsgruppe Boden, 2005. Bodenkundliche Kartieranleitung (KA5) (Soil survey instruction). 5th Edition. Hannover. E. Schweizerbart'sche Verlagsbuchhandlung, Stuttgart, 438 pp. In German. ISBN 978-3-51095920-4.

Bockheim, J.G., Gennadiyev, A.N., Hartemink, A.E., Brevik, E.C., 2014. Soil- 
forming factors and Soil Taxonomy. Geoderma 226-227, 231-237. https://doi.org/10.1016/j.geoderma.2014.02.016

Braunersreuter, M., Burghardt, W., 2002. Organic Matter Accumulation in Stony Soils from Hard Coal Mining Spoil. Proceedings of $17^{\text {th }}$ World Congress of Soil Science, Bangkok, August 14-22, 2002, electronic version, 1670-1/8. http://citeseerx.ist.psu.edu/viewdoc/download?doi $=10.1 \cdot 1.9 .5522 \&$ rep $=$ rep $1 \&$ type $=$ pdf

Burghardt, W., 1989a. C-, N- und S-Gehalte als Merkmale der Bodenbildung auf Bergehalden (C-, N- and S- content as features of soil formation on mining spoil). Mitteilungen der Deutschen Bodenkundlichen Gesellschaft 59II, 851-856. (In German). https://www.dbges.de/wb/media/mitteilungen_dbg/Mitteilungen\%20der\%20DBG\%201989_59\%20H2.pdf

Burghardt, W., 1989b. Haldenbegrünung durch Oberflächengestaltung (Greening of mining spoil heaps by surface modeling). Mitteilungen der Deutschen Bodenkundlichen Gesellschaft 58, 233-234. (In German). https://www.dbges.de/wb/media/mitteilungen_dbg/Mitteilung en\%20der\%20DBG\%201989_58.pdf

Burghardt, W., 1989c. Bodenbeschaffenheit und Pflanzennährstoffgehalte der Bodenvarianten des Begrünungsversuches Bergehalde Waltrop (Soil characteristics and plant nutrient contents of soil variants of the greening trial mine spoil heap Waltrop). Mitteilungen der Deutschen Bodenkundlichen Gesellschaft 58, 219-225. (In German). https://www.dbges.de/wb/media/mitteilungen_dbg/Mitteilungen\%20 der\%20DBG\%201989_58.pdf

Burghardt, W., 1994. Soils in urban and industrial environments. Zeitschrift. f. Pflanzenernährung und Bodenkunde 157, 205-214. https://doi.org/10.1002/jpln.19941570308

Burghardt, W., (1997). Skelettgehalte in Böden aus technogenen Substraten (Skeleton content in soils from technic substrates). Mitteilungen der Deutschen Bodenkundlichen Gesellschaft 85/III, 1115-1118. (In German). https://www.dbges.de/wb/media/mitteilungen_dbg/Mitt eilungen\%20der\%20DBG\%201997_85\%20H3.pdf

Burghardt, W., Niggemeyer, M., 2002. Quality of stony soils and their remediation by humus formation - results from the field trial on shales from hard coal mining of Waltrop, Ruhr area. [In:] Al-Awadhi, N.M., Taha, F.K. (Eds.), new technologies for soil reclamation and desert greenery. Amherst Scientific Publishers, Amherst, Massachusetts USA, 255-268.

Burghardt, W., Morel, J.L., Zhang, G-L., 2015. Development of the soil research about urban, industrial, traffic, mining and military areas (SUITMA). Special Issue: Soils of anthropized environments. Soil Science and Plant Nutrition 61, Supplement 1: 3-21. https://doi.org/10.10 80/00380768.2015.1046136

Burghardt, W., Schneider, Th., 2016. Bulk density, and content, density and stock of carbon, nitrogen and heavy metals in vegetable patches and lawns of allotment gardens in the north-western Ruhr area, Germany. Journal of Soils and Sediments 18(2), 407-417; https://doi. org/10.1007/s11368-016-1553-8

Burghardt, W., Heintz, D., Hocke, N., 2018. Soil Fertility Characteristics and Organic Carbon Stock in Soils of Vegetable Gardens Compared with Surrounding Arable Land at the Center of the Urban and Industrial Area of Ruhr, Germany. Eurasian Soil Science 51, 9, 1067-1079.

Daniels, W.L., Zipper, C.E., 2018. Creation and management of productive mine soils. Virginia Cooperative Extension, Pub. 460-121, Virginia Tech, Blacksburg, VA. https://www.pubs.ext.vt.edu/460/460-121/460121.html

Deutscher Wetterdienst, 2019. Niederschlag: vieljährige Mittelwerte 1981-2010 (Precipitation; quarterly mean 1981-2010). (In German). https://www.dwd.de/DE/leistungen/klimadatendeutschland/mittelwerte/nieder_8110_akt_html.html?view=nasPublication\&nn=16102 Deutscher Wetterdienst (2019): Niederschlag: vieljährige Mittelwerte 1981-2010

https://www.dwd.de/DE/leistungen/klimadatendeutschland/mittelwerte/ nieder_8110_akt_html.html?view=nasPublication\&nn=16102.

Down, C.G., 1975. Soil development on colliery waste tips in relation to age. Journal of Applied Ecology 12, 613-635.

Flint, A.L., Childs, S., 1984. Physical properties of rock fragments and their effects on available water in skeletal soils. In: Nichols, J.D. ez l. Soil Science Society of America special publication number 13, 91-103: Madison.

Hackelberg, R., Mansfeld. T., Kögel-Knabner, I., 1995. Bodenentwicklung auf ehemaligen Bergehalden am Beispiel der Zeche Zollern II in Dortmund-Bövinghausen (Soil development of mining spoil heaps, example mine Zollern II in Dortmund-Bövinghasen). Mitteilungen der Deutschen Bodenkundlichen Gesellschaft 76/II, 1317-1320. (In German).

Haering, K.C., Daniels, W.L., Galbraith, J.C., 2004. Appalachian mine soil morphology and properties: effects of weathering and mining method. Soil Science Society of America Journal 68, 1315-1325. https://doi. org/10.2136/sssaj2004.1315

Hantschel, R., Beese, F., Hoewe, R., 1992. Bedeutung von Steinen für den Wassertransport. Ein idealisierter Laborversuch. (Importance of stones for the water transport. A labour experiment). Mitteilungen der Deutschen Bodenkundlichen Gesellschaft 67, 79-82. (In German). IUSS Working Group WRB, 2015. World Reference Base for Soil Resources 2014, update 2015. International soil classification system for naming soils and creating legends for soil maps. World Soil Resources Reports No. 106. FAO, Rome.

Jackson, M.L., 1958. Soil chemical analysis. Englewood Cliffs, New York.

Jochimsen, M.E.A., 1987. Vegetation development on mine spoil heaps - a contribution to the improvement of derelict land based on natural succession. [In:] Miyawaki, A., Bogenrieder, A., Okuda, S., and White, S. (Eds), Vegetation Ecology and Creation of New Environments, Proc. Intern. Symposium Tokio 1984, Tokai University Press, 245.

Jochimsen, M.E.A., 1989. Begrünung von Berghalden auf der Grundlage der natürlichen Sukzession. Mitteilungen der Deutschen Bodenkundlichen Gesellschaft 58, 226-232. (In German).

Jochimsen, M.E.A., 1996. Reclamation of Colliery mine spoil heaps founded on natural succession. [In:] Hüttl, R.F., Wisniewski, J. (Eds), Mine Site Recultivation. Water, Air and Soil Pollution 91, 99-108.

Jochimsen, M.E., 2001. Vegetation development and species assemblages in a long-term reclamation project on mine spoil. Ecological Engineering 17, 187-198. https://doi.org/10.1016/S0925-8574(00)00158-0

Kelly, R.E., Kelly, R.E., 1987. Prediction of some mine spoil characteristics from exploration drill hole logs. Environmental Workshop $1987 \mathrm{~Pa}-$ pers, Australian Mining Industry Council, Dickson, ACT, 49-65.

Kerth, M., 1988. Die Oxydation des Pyrits - dominierender chemisch Verwitterungsvorgang in Bergehaldenrohböden des Ruhrgebiets (The oxidation of Pyrite-dominant chemical weathering process in mine spoil raw soils of the Ruhr area). Mitteilungen der Deutschen Bodenkundlichen Gesellschaft 56, 375-380. (In German).

Kompała-Bąba, A., Bierza, W., Błońska, A. et al., 2019. Vegetation diversity on coal mine spoil heaps - how important is the texture of the soil substrate? Biologia 74, 419-436. https://doi.org/10.2478/s11756-01900218-X

Maiti, S.K., Saxena, N.C., 1998. Biological reclamation of coalmine spoils without topsoil: An amendment study with domestic raw sewage and grass-legumes mixture. International Journal of Surface Mining, Reclamation and Environment 12, 87-90. https://doi.org/10.1080/092081 18908944028

Maiti, S.K., Ghose, M.K., 2005. Ecological restoration of acidic coal mine overburden dumps-an Indian case study. Land Contamination and Reclamation 13(4), 361-369.

Morel, J.L., Chenu, C., Lorenz, K., 2014. Ecosystem services provided by soils of urban, industrial, traffic, mining, and military areas (SUITMAs). Journal of Soils and Sediments 15, 1659-1666. https://doi. org/10.1007/s11368-014-0926-0

Nichols, J.D., Brown, P.L., Grant, W.J. (Eds.) 1984. Erosion and productivity of soils containing rock fragments. Soil Science Society of America special publication number 13, Madison, WI 53711.

Niggemeyer, M., Burghardt, W., 1996. Physikalische Merkmale der Bod- 
envarianten des Steinkohlebergehaldenversuches Waltrop (Physical characteristics of soil variants of mining spoil trial Waltrop). Mitteilungen der Deutschen Bodenkundlichen Gesellschaft 84, 41-44. (In German). https://www.dbges.de/wb/media/mitteilungen_dbg/Mitteilu ngen\%20der\%20DBG\%201997_84.pdf

Pietrzykowski, M., Krzaklewski, W., 2018. Reclamation of mine lands in Poland. [In:] Prasad, M.N.V., Favas, P., Maiti, S.K. (Eds.), Bio-Geotechnologies for Mine Site Rehabilitation Elsevier, Amsterdam-OxfordCambridge, 493-513. ISBN 978-0-12-812986-9

Rytter, R.-M., 2012. Stone and gravel contents of arable soils influence estimates of C and N stocks. CATENA 95, 153-159. https://doi.org/10.1016/ j.catena.2012.02.015

Sabiene, N., Kusliene, G., Zaleckas, E., 2010. The influence of land use on soil organic carbon and nitrogen content and redox potential. Zemdirbyste 97, 15-24.

Savage, S.M., Stevenson, F.J., 1961. Behavior of Soil Humic Acids Towards Oxidation with Hydrogen Peroxide. Soil Science Society Proceedings 25, 35-39.

Schneider, S., 1989. Bodenkundliche Untersuchungen auf der Bergehalde Waltrop im Rahmen eines Großversuches der Haldenrekultivierung (Soil investigations of the mining spoil heap Waltrop within the scope of a large scale trial of mining spoil restoration). Mitteilungen der Deutschen Bodenkundlichen Gesellschaft 58, 211-218. (In German). https://www.dbges.de/wb/media/mitteilungen_dbg/Mitteilungen\%20 der\%20DBG\%201989_58.pdf

Schulin, H., Selim, M., Flühler, H., 1995. Bedetung des Bodenskeletts für die Verlagerung von gelösten Stoffen in einer Rendzina. (The importance of soil skeleton for the transport of dissolved compounds in a Rendzina (Calcaric Leptosol)). Zeitschrift Deutsche Geologische Gesellschaft 136, 397-405. (In German).
Sheoran, V., Sheoran, A.S., Poonia, P., 2010. Soil Reclamation of Abandoned Mine Land by Revegetation: A Review. International Journal of Soil, Sediment and Water 3(2), Article 13. Available at: https://scholarworks.umass.edu/intljssw/vol3/iss2/13

Uzarowicz, Ł., Skiba, S., 2011. Technogenic soils developed on mine spoils containing iron sulphides: Mineral transformation as an indicator of pedogenesis. Geoderma 163, 95-108. https://doi.org/10.1016/ j.geoderma.2011.04.008

Uzarowicz, Ł., 2011. Technogenic Soils developed on mine spoils containing iron sulfides in select abandoned industrial sites: Environmental Hazards and Reclamation Possibilities. Polish Journal of Environmental Studies 20(3), 771-782.

Weiss, J., Burghardt, W., Gausmann, P., Haag, R., Haeupler, H., Hamann, M., Leder, B., Schulte, A., Stempelmann, I., 2005. Nature returns to abandoned industrial land: Monitoring succession in urban-industrial woodlands in the German Ruhr. [In:] Kowarik, I., Körner, St. (Eds.), Wild Urban Woodlands. Springer Berlin Heidelberg, 143-162. DOI https://doi.org/10.1007/3-540-26859-6_9

Woch, M.W., Radwańska, M., Stefanowicz, A., 2013. Flora of spoil heaps after hard coal mining in Trzebinia (southern Poland): effect of substratum properties. Acta Botanica Croatia 72 (2), 237-256. https://doi. org/10.2478/v10184-012-0020-x

Zimmermann, P., Burghardt, W., 1987. Untersuchungen zum Einfluss der Reliefausformung auf die Ausgangsstadien der Bodenbildung und die Entwicklung des Bodentierbesatzes auf Bergehalden (Investigations to the influence of the molding of relief on the initial conditions of soil formation and the development of soil animal stocking on mining spoil heaps). Verhandlungen Gesellschaft für Ökologie XVII, 815-818, Göttingen (1989). (In German). 